\title{
4. Insights from John Maynard Keynes
}

\section{Bradley Bateman ${ }^{1}$}

What would John Maynard Keynes think about these trying economic times? ${ }^{2}$ These days this question immediately raises questions about the stimulus package. Was the stimulus package too big or was it too small? That is the big Keynesian argument today. Did the almost $\$ 800$ billion package cause enough stimulus to lift the economy out of a bad recession, or was it too small, that we need more stimulus to the economy?

However, if we are considering what John Maynard Keynes would have said about these rough economic times, I would say it is the wrong question. I do not think this is the particular debate that Keynes would have wanted to be in. He liked debates, so I am sure he would have gotten into the debate, but he would not have seen this as the core question.

Let us start with what Keynes thought caused the Great Depression - or as Keynes would have called it, the 'slump'. Between 1923 and 1939 there was only one year when unemployment was under 10 percent in Britain. After World War I, Britain settled into a very bad economic slump, 
which lasted for several years before the Great Depression started in 1929. Keynes had already been working for many years trying to explain why the British economy was not performing as well as it might have. But when the Great Depression hit, he really went to work trying to explain what causes a capitalist economy to go through cycles.

The US economy boomed during much of the last decade, but then in 2008 we entered a steep recession. Keynes wanted to answer the question: What causes economies to rise and fall like this? His basic answer was that private investment rises and falls. In The General Theory of Employment, Interest and Money (1936), he identified three causes of demand in the economy. Households consume things, businesses invest, and the government spends money on goods and services. (He purposely avoided discussing a fourth cause of demand, the international sector.) But the primary cause of the cycles in the business cycle - what he called the trade cycle - was fluctuation in investment. Keynes postulated that consumption by households is very stable - offering the explanation that people try to stick to their habitual patterns of consumption. When things get bad they do not cut their consumption back as far as their income. And when their income goes up they do not spend all of the extra income they get, they save some of it. In his time government expenditure was not a very large part of the total demand in an economy. 
At the time he wrote, GDP or GNP figures were not available but he concluded, based on other economic statistics, that investment fluctuates considerably. Businesses can get excited about their profit expectations. If businesses think that they are going to be profitable they start investing in more plant and equipment, that is they build more factories and buy more machines. But if they are worried that profits will fall, if they are worried that they will not continue to make increasing profits, they will cut back. These rises and drops in investment are what cause the economy to rise and fall. So you have a business cycle because you have an investment cycle.

What could cause a slump? In The General Theory Keynes argued that when the economy falls into a bad slump it does not have to rise back up again, because businessmen may be so pessimistic about the future, they may think that it is not possible to make profits in the future so that they will not start to invest again. When investment falls, that takes the whole economy down. When the economy gets down in the slump, he says, it could stay there with mass unemployment for a long period of time. There is not necessarily an automatic corrective mechanism.

When there is too much demand in a market, price rises. The price rise causes companies to produce more, so more is produced. When demand falls, there is too much of a good in a market, price falls. That is a signal to companies that they should cut back on the production of 
that good. This is Friedrich Hayek's argument. He calls prices the 'telecommunication system' of the economy. Telecommunication was not a common word in 1946, so this was very prescient. And he is right - if you are talking about the market for milk or apples, this is probably a good way to describe the market. But Keynes says, in the case of private investment by capitalists, demand can fall and it does not have to rise again. You cannot tell workers to just take lower wages and then they can find jobs. Companies are letting people go, and they are not creating new jobs, and they are not opening up those jobs for workers again. The jobs have simply disappeared. Today, American businesses are sitting on the largest cash holdings in history. They are not making new investments right now. It is something like what Keynes talked about - they are worried about profitability. They may be worried about their profitability because they do not know what's going to happen with the Healthcare Act. They may be worried about their profitability because they do not know what's going to happen with the recovery from the recession. They may be worried about their profitability because they do not know if housing prices are going to rise again. But for some reason they have a bad economic outlook, and they are choosing not to invest in the same way that they did during most of the last decade. This is what Keynes was talking about, low investment, which causes low economic activity.

In describing investors' attitudes, Keynes used 
the phrase 'animal spirits'. ${ }^{3}$ Investors might have high animal spirits, which means they feel very optimistic about the economy, very optimistic about the future, very optimistic about their opportunities and new markets. Or they can have low animal spirits. They could feel that there is not much reason to invest; they could be thinking it would be better to wait a year. If they have low animal spirits, then investment will be low and the economy will do badly.

What, then, should we do about that slump? What can we do that would cause the economy to pick back up? Keynes published his great book in 1936, had a major heart attack in 1937, and did very little for about two years. Then as World War II began he went to work in the Treasury. He did not have a formal job there - he was just Keynes. They gave him an office and would simply take things to him for his opinions. He died in 1946, so he never again lectured at the University of Cambridge. Although he published some pamphlets, he did not publish another book.

The Keynesians are economists who took his legacy after his death in 1946 and tried to build an economic system out of it. In a traditional Keynesian model - this is not what Keynes said, but what his academic followers argued - when the economy slumps you can turn to any one of those three sectors: households, businesses or government. If you can increase spending in any of those sectors, you can push the economy back up. The simplest and easiest form of this is to very 
directly increase government spending. ${ }^{4}$ The next easier way would be to cut people's taxes so that consumption would go up. Let people keep more of their income, and they can consume more. Keynes was not a fan of this approach. He did not believe that trying to adjust tax rates to push consumption up and down was very useful. James Meade, a young economist in the British government at this time (who later won a Nobel Prize), developed a complicated scheme for adjusting what we would call Social Security taxes. Keynes wrote a memo to him saying he did not think that you can get big shifts in spending by changing taxes on people. This comes back to his belief that consumption was very stable. So Keynes himself was not an advocate for trying to use consumption to boost the economy.

He did believe in using one kind of government spending - public works projects, such as building new bridges on the highways, new post office buildings, and new airports. He believed infrastructure projects like this were a way to stimulate the economy, but he did not believe that in and of themselves these expenditures would be enough to raise and stabilize the economy. He believed that they would have a knock-on effect on investment. The economy is low, it has slumped because investors have poor animal spirits. Keynes believed that if investors came to understand that we would roll out infrastructure projects when the economy started to go down, then their profit expectations would not fall. After 
all, they would not think so many people would become unemployed; they would not think sales would fall so much at the mall; they would not think that houses would be hard to sell - because people would still be employed. So the main thing for Keynes was to keep people in work. This is hard for many to understand today, because his basic model was taken and rebuilt by other people. In his graphs and equations, employment was the variable of interest. For Keynes the important measure of welfare was how many people are working in an economy. Modern textbooks tend to focus on GDP, but for Keynes it was the number of people working.

He believed that if we thought the government could take some infrastructure projects off the table, get them going - build more roads, build more bridges, construct more airports - capitalists would come to believe that they did not have to get so blue about the economy. Their animal spirits would not fall so far. However, Keynes never argued that you could boost the economy to a growth path and keep it there. He argued that you could dampen swings in investment, and you could certainly keep investment from falling off the table and getting stuck at a low level. This was a direct contradiction of what Hayek would say. Hayek would say there is nothing the government can do which will make the economy better, nothing. Let capitalists and consumers have at it in the market, and everything will be okay. Just keep the government out of it. 
Keynes disagreed fundamentally. He said there are aspects of capitalist society, especially investor expectations and their fears about profits, which can cause this whole system to fall into a state of high unemployment and low activity. And it is possible to nudge the economy out of inactivity, to get things going again. He never said that the government could exactly hit some economic target. This is an idea that came from one of the first great Keynesian texts published in the late 1940s, Functional Finance by Abba Lerner (see Lerner, 1983). Lerner wrote about being able to drive the economy as if you have a steering wheel. Keynes thought this was nonsense. He did not believe you could steer the economy like you were driving a car, because he understood that the economy was always subject to fluctuations on the whim of investors, that animal spirits could rise or collapse at any time.

Now, my most shocking point - Keynes did not believe in running government budget deficits. Keynes wrote a campaign pamphlet, several hundred pages long, with one of his former students, Hubert Henderson, in 1928 for the 1929 general election. Keynes was a lifelong member of the Liberal Party. He was not a member of the Labour Party nor was he a Conservative (Tory). At this time in Britain, the Liberal Party was collapsing, and Labour was about to overtake them as a second party. But, despite the fact that the Liberal Party was losing electoral power, Keynes never realigned with another party. In many ways 
he was Libertarian. ${ }^{5}$ The title of the pamphlet was 'Can Lloyd George Do It?' David Lloyd George, the Prime Minister during and just after World War I, would be the Liberals' candidate in the 1929 election. The shocking proposal Keynes and Henderson made in 'Can Lloyd George Do It?' was a $£ 250$ million public works stimulus package. At $\$ 5$ to the pound, that would have been over a billion dollars - an unimaginable amount of money at the time, a huge stimulus package.

Today we might conclude that the government would need to borrow money and run a deficit to finance such a stimulus package, but Keynes and Henderson did not propose running a deficit. At this time when the British government sold bonds, the bonds did not have expiration dates. When you lent money to the British government it was until they bought the bond back. Wealthy people bought them to guarantee income to their heirs and themselves. These were called gilts, because the bonds had a gold-gilded edge on them. But unlike what economists like James Buchanan and Richard Wagner have argued, this ability of the government to borrow money and never pay it back did not make the British government become irresponsible (Buchanan and Wagner, 1977). Instead, each year the budget would set aside funds for paying back bonds. The money that was kept for buying back issues of bonds was called a sinking fund. Keynes and Henderson looked at the sinking fund and said, there is more than $£ 250$ million pounds in the sinking fund, so 
we could take the money out of the sinking fund and use that for the public works projects; that will stimulate the economy, cause more tax collection, and we will put the money back. They did not even want to borrow money and run a deficit! They wanted to use the sinking fund to do this.

In the early 1920s the Liberal Party started a series of summer schools, inviting leading journalists, academics, and what today we would call 'thought leaders'. They would run a summer workshop where they would try to generate new ideas for the Liberal Party. Keynes went to these summer schools for several years. Around 1924, he gave a lecture about the importance of reforming the British government's accounts, arguing that the accounts were not being done on a proper accounting basis. Most businesses have a regular annual budget and a capital budget, but the British government put the two together. Keynes argued that while a government should never run a deficit in its ordinary budget it was acceptable to borrow money to spend on investment - but only for things that are honestly investments, like building a highway into a new area that causes new stores, houses and apartments to be built, all that will generate income - and that income can come back to pay off the bonds that were sold in order to make the investment. For example, you could borrow money to build an airport and then charge the airlines or passengers fees for using the airport. This is an investment that generates income, and that generated income will pay off the borrowed money. 
Keynes said over and over again in his work in the government during World War II, when he was writing white papers on postwar economic policy - white papers on full employment - and he said repeatedly in his private correspondence that he had no intention of supporting regular government budget deficits. So when people ask, 'Is the stimulus too big or too small?' they are not asking a question that makes a lot of sense to Keynes. Number 1, you are not talking about what is going to happen to private investment. But number 2, you are talking about a stimulus package that had a lot of consumption in it. And that was not his purpose. I cannot fathom the idea of how to get Keynes - who has been dead for almost 70 years - to speak about the size of the stimulus package. He would not have advocated the stimulus package in the form that we had it. I think Keynes would have endorsed the pieces of the stimulus package tied to infrastructure projects.

It is very easy to put words in a dead man's mouth. That is how scholars make their living. But it is hard for me to put words in Keynes's mouth because he changed his mind all the time. But I do see across the arc of those last ten years of his life a very consistent concern with questions of what caused poor economic activity in a capitalist economy, what you could do about that, and what the potential for that was.

In his life Keynes wrote three very well-known books: A Tract on Monetary Reform (1923), A Treatise 
on Money (1930), and The General Theory (1936). A Tract on Monetary Reform was almost completely written as newspaper articles, and then reprinted. It was cutting-edge economics at the time, but also very popular. It was accessible enough that it educated a newspaper reader in Europe to read it. These were published in postwar reconstruction supplements for the Manchester Guardian. His argument was a plea to the monetary authorities to try to stabilize the price level, in a time of hyperinflation in Europe. We all know the stories about Germans going out to get a loaf of bread with a wheelbarrow full of money. Keynes made an impassioned plea in A Treatise on Money for central banks, like the Bank of England, to stabilize price levels. He made a simple argument that the monetary authorities should either raise interest rates to slow the economy down, or lower interest rates to speed the economy up, and that the trick was just getting that interest rate at the right level.

In both of those books Keynes had what economist Don Patinkin has called a 'magic formula' mentality. He believed that there were knobs for economic policy, and if you got the knobs in the right place then the economy would perform just the way you want it. Roger Backhouse and I have argued in Capitalist Revolutionary: John Maynard Keynes (2011) that - if you follow through Keynes's scholarly writings, public writings, journalism, and lectures - late in 1933 Keynes finally gave up on the magic formula mentality. He finally stopped 
believing that there were knobs that you could turn to get the economy the way you wanted. He developed a much more subtle understanding of how a capitalist economy works. This is exactly the moment when he brought in capitalists' expectations for profits and expectations about how the economy is going to work. He became less overtly optimistic about the possibilities for economic policy in the spring of 1933, just after he had figured out the multiplier concept, which actually his research assistant had figured out for him. At that time he wrote a pamphlet called 'The Means to Prosperity', which was originally a set of four op-ed pieces in The Times of London. He pushed the idea that with a multiplier, you just have to ramp up government expenditure and can get right where you want to get. The idea met a poor reception (like much of his writing) and that is when he stopped believing in it. It is the abandonment of that magic formula mentality that I think really characterizes his later work, and that helps us to understand some of his concerns.

Since I am the guest of the Wake Forest University BB\&T Center for the Study of Capitalism, I want to finish with a couple of questions that I think Keynes's analysis raises about capitalism. We are studying capitalism, living in a time when there is not an obvious alternative. For better or worse, after the financial crisis of 2008 there is not anywhere in the world where the popular mind has turned to socialism as an answer. The reality is we live in a world in which 
there is good capitalism and bad capitalism. There is capitalism that works for people, that employs people, provides consumer goods for people, provides them with the means to a good life. I want to profess to you the material things that the economy gives you are not the most important things in your life. They are the means to other ends. Because I come from a blue-collar family, because my father has an eighth-grade education, I care a lot about money. But it is not the most important thing. But I think it is very hard to have the good things in life if you are not materially well off. If you do not have a place to live, do not have food on your table, do not have things to wear, it is very, very hard to live a good life. But those are means to a good life. They are not ends unto themselves.

So the question becomes: Do we have a good form of capitalism, or do we have a bad form of capitalism? Clearly, capitalism does not always work for people. If Keynes is correct, then a capitalist economy will occasionally go through periods of deep recession. The economy will turn down, there will be large-scale unemployment which will hurt a lot of people - just as we have seen in this country over the last three years. The question is: What are our responsibilities to the people who are hurt by unemployment? We agree to live in a capitalist system; agreeing to live in a system that we know will periodically throw people out of work. In Keynes's argument those workers are unemployed not because of their own 
actions. They cannot do anything about it. They are unemployed because of investment decisions made by other people. It is not their fault.

In the case of the current recession and recovery, the receipts of the government have fallen through the floor but governments everywhere - Japan, Europe, North America - have spent more money because of the recession. So budget deficits have gotten ridiculously large. There are many in the political sphere who say, 'Ah-ha, look at those deficits, we have got to stop government spending.' But what about the people who were hurt, who are out of work through no choice of their own? They are not out of work because they joined a union or because they refused to work for less money. They are out of work because of somebody else's decision. The political outcome of the slump is to cut the support for those people. Is that the best approach? That is the first question that I want to leave you with.

The second question that I want to leave you with is this: If Keynes is right that in order to have a relatively high level of employment we have got to humor capitalists, got to make them optimistic, got to keep them feeling good, keep those animal spirits up, then how much spirit lifting do we have to do? What is the legitimate exercise in sustaining capitalists' expectations? If it is true that we have to make capitalists feel good about their future, then what does that say about the legitimacy of their role in the political process? Is that fair to everyone else? 
What are the things that make capitalism work? And what are the things that make it a fair system for all the people who participate in it?

\section{Notes}

1. This talk was given at Wake Forest University on April 19, 2012. I took my first economics course as an undergraduate here at Wake Forest and want to dedicate this talk to my first economic professor, Van Wagstaff, a remarkable lecturer who helped give me a love of the subject.

2. He was called Maynard in his life. His father was John Neville Keynes. So they went by 'Neville' and 'Maynard', not 'John'.

3. There is a debate about where he got the term 'animal spirits'. Some argue that it comes from Jane Austen, whom Keynes loved.

4. There was actually an argument developed by one of the early famous Keynesians, Alvin Hansen, that investment opportunities were disappearing in modernity. Just as many had argued 40 or 50 years earlier that the western frontier was closing, Hansen argued that investment opportunities were closing down. He believed that government would have to be increasingly involved in making the economy work. That was the only place we would get enough demand to sustain economic growth. That is Hansen's argument, not Keynes's.

5. Keynes was a homosexual for the first part of his life; he then had a monogamous marriage to a beautiful ballerina for the second half of his life. He led a very unconventional life and believed that the government had no business putting its nose into any part of his private life. When he died in 1946 it was still a criminal offense to engage in a homosexual act in Britain. Had he ever been caught, he could have been tried, as Oscar Wilde was. He had reason to fear the government, and throughout his life he was a Liberal. 


\section{References}

Backhouse, R. and B.W. Bateman (2011), Capitalist Revolutionary: John Maynard Keynes, Cambridge: Harvard University Press.

Buchanan, J.M. and R.E. Wagner (1977), Democracy in Deficit: The Political Legacy of Lord Keynes, New York: Academic Press.

Keynes, J.M. (1923), A Tract on Monetary Reform, London: Macmillan and Co.

Keynes, J.M. (1930), A Treatise on Money, New York: Harcourt, Brace and Company.

Keynes, J.M. (1936), The General Theory of Employment, Interest and Money, New York: Harcourt, Brace and Company.

Lerner, A.P. (1983), 'Functional Finance and the Federal Debt', in D.C. Colander (ed.), Selected Economic Writings of Abba P. Lerner, New York: New York University Press, pp. 297-310. 